\title{
New Culicoides Latreille of the subgenus Mataemyia Vargas from Pará, Brazil (Diptera: Ceratopogonidae)
}

\author{
Maria Luiza Felippe-Bauer ${ }^{1 /+}$, Tiago do Nascimento da Silva', Rosimeire Lopes da Trindade ${ }^{2}$ \\ ${ }^{1}$ Laboratório de Diptera, Instituto Oswaldo Cruz-Fiocruz, Rio de Janeiro, RJ, Brasil \\ ${ }^{2}$ Coordenação de Zoologia, Entomologia, Museu Paraense Emílio Goeldi, Belém, PA, Brasil
}

Two new species of Culicoides Latreille of the Neotropical subgenus Mataemyia Vargas are described and illustrated based on female specimens from Juruti, Pará, Brazil and compared with their similar congeners. This paper also presents a diagnosis of the subgenus Mataemyia and a systematic key for the identification of the 19 species of the subgenus.

Key words: Culicoides (Mataemyia) aldomari sp. nov. -

Culicoides (Mataemyia) sherlocki sp. nov. - bloodsucking midges - Neotropical Region

The subgenus Mataemyia Vargas is represented by the species included in the discrepans species group by Wirth and Blanton (1973). This group was formally characterized by Wirth and Soria (1981) based on eight Neotropical species. Borkent and Spinelli (2000) recognize the subgenus based on Culicoides mojingaensis Wirth \& Blanton, type species of Mataemyia. The subgeneric classification has been followed by several authors including the more recently and comprehensive paper by Borkent (2011).

From the 273 Neotropical species reported in Borkent (2012), 17 belong to Culicoides of the subgenus Mataemyia. In the revision of the biting midges from the Amazon Basin, Wirth and Blanton (1973) cited three species of this subgenus (Culicoides albuquerquei Wirth \& Blanton, Culicoides bricenoi Ortiz and Culicoides wallacei Wirth \& Blanton). Trindade and Gorayeb (2005) recorded Culicoides daviesi Wirth \& Blanton for the first time from Brazilian Amazonia in Outeiro Island, state of Pará (PA), Brazil. Recently, Spinelli et al. (2007) described Culicoides felippebauerae from the state of Amazonas, so five species from this subgenus are presently known inhabiting northern Brazil.

In the present paper, we describe and illustrate two new species from the municipality of Juruti, PA, based on females specimens collected by CDC light trap and discuss the similarities and differences with their related species of the subgenus Mataemyia. With the addition of the two new species described here, there are now 11 species of Culicoides (Mataemyia) known from Brazil (7 from the Brazilian Amazon Region) and 19 from the Neotropical Region. As the available key for subgenus Mataemyia was provided by Wirth and So-

Financial support: $\mathrm{CNPq}$

+ Corresponding author: mlfbauer@ioc.fiocruz.br

Received 16 March 2012

Accepted 18 April 2012 ria (1981) for only eight species included in discrepans group, we update the key for the identification of the 19 species belonging to the subgenus and made a synopsis of the subgenus Mataemyia.

\section{MATERIALS AND METHODS}

The specimens are slide-mounted in phenol-balsam in the manner described by Wirth and Marston (1968). The new species is deposited in Emílio Goeldi Museum (MPEG) (Invertebrates Collection) and Oswaldo Cruz Institute (Ceratopogonidae Collection) (CCER), Brazil. Diagnostic characters were illustrated using a camera lucida attached to an Olympus BH-2 microscope and the plates were prepared using Photoshop GIMP Portable. Microphotographs of the wings were taken with a Nikon Eclipse E-800. The general terminology used is that employed for Culicoides by Felippe-Bauer (2003). Terms for structures follow the Manual of Central America Diptera (Brown et al. 2009). The measurements of the spermathecae are in micrometers and those of the wings are in millimetres. Meristic information is given as range, following by the mean and number of specimens examined.

\section{Culicoides of the subgenus Mataemyia Vargas}

Diagnosis - Medium to large-sized species (wing with 0.80-1.8 mm). Eyes bare. Palpus moderately swollen; third segment with moderately broad pit located on midlength or subapical; palpal ratio (PR) 1.8-3.0. Antenna usually with transition in length between proximal and distal series; sensilla coeloconica present on flagellomeres 1, (4), (5), 6-8 (except in C. albuquerquei 1, 6-12); antennal ratio (AR) $0.75-1.70$ (usually more than 1.00 ). Scutum dark brown with prominent pattern of yellowish spots. Wing with distinct pale spots; poststigmatic pale spot in $\mathrm{r}_{3}$ usually as inverted L-shaped, nearly isolating a small dark spot behind second radial cell; sometimes this small dark spot is connected to the oblique dark line in $\mathrm{r}_{3}$, separating the poststigmatic pale spots; distal pale spot in $r_{3}$ usually reaching the anterodistal portion of wing margin; $\mathrm{CuA}_{1}$ and $\mathrm{CuA}_{2}$ usually dark; wing base usually with broad pale spot extending from costal mar- 
gin to anal cell; macrotrichia in distal half of wing. Legs dark brown with distinct pale bands characteristics of each species; hind tibial comb with four spines (rarely 5 or 6). Two (rarely 1) spermathecae present. Male tergite 9 with long, subparallel apicolateral processes (rarely slender and well separated). Gonocoxite moderately stout, dorsal and ventral root moderately to well developed; gonostylus curved, slender. Aedeagus triangular with rounded basal arch extending 0.5 of total length, tapering to bifid or slender, single apex. Parameres separate; mid-portion long, slender; apical portion tapered, abruptly bent ventrally, mesally directed, with fringe of fine spicules or as simple, filiform tip.

Key to the species of the Culicoides (Mataemyia) Vargas (primarily to females)

1. Sensilla coeloconica on flagellomeres $1,6-12 \ldots \ldots . . .$. C. albuquerquei Wirth \& Blanton 6-8.

- Sensilla coeloconica on flagellomeres 1, (4), (5),

2. One spermatheca; hind femur dark to tip; sensilla coeloconica on flagellomeres 1, 5-8. .

- Two spermathecae; hind femur various; sensilla coeloconica on flagellomeres 1, (4), (5), 6-8.

3. Mid femur dark to tip; hind tibial comb with six spines; second radial cell pale in mid portion with extreme base and tip in dark spots.

C. daviesi Wirth \& Blanton

- Mid femur with subapical pale band; hind tibial comb with four spines; second radial cell in dark spot...... C. felippebauerae Spinelli

4. Base of the wing with a pale spot restricted to the area near basal arculus..

- Base of the wing broadly pale, sometimes extending from costal margin to anal cell.

5. Large species, wing length $1.45 \mathrm{~mm}$; one distal pale spot in anal cell; distal pale spot in $\mathrm{r}_{3}$ single, irregular, slightly meeting wing margin in reduced breadth....... C. volcanensis Wirth \& Blanton

- Smaller species, wing length $1.22-1.38 \mathrm{~mm}$; two distal pale spot in anal cell; distal pale spot in $r_{3}$ various, broad meeting wing margin.

6. Hind tibia broad pale apically; single distal pale spot in $\mathrm{r}_{3}$; distal pale spot in $\mathrm{M}_{1}$ reaching wing margin; distal portion of the aedeagus rounded on lateral margin, ending in a pair of posteriorly directed processes.

C. dalessandroi Wirth \& Barreto

- Hind tibia with apical, narrow pale rings; double distal pale spot in $r_{3}$; distal pale spot in $M_{1}$ far from wing margin; distal portion of the aedeagus slightly expanded on lateral margin, ending in a pair of divergent lateral processes. C. huyanacapaci Felippe-Bauer

7. Hind femur dark to tip. ... 8

- Hind femur with subapical pale band. 11

8. Second radial cell long, $2 x$ longer than first; AR $1.47-1.70$ 9

- First and second radial cells nearly similar in length; AR $0.75-0.84$...
9. $r_{3}$ with two large pale spots, the distal one located in distal portion of cell reaching anterodistal wing margin; sensilla coeloconica on flagellomeres 1,6-8; AR 1.70.......

C. bricenoi Wirth

$-r_{3}$ with three small, round, pale spots, the distal one located in middle of cell; sensilla coeloconica on flagellomeres 1, 5-8; AR 1.47. C. cuiabai Wirth

10. Small species, wing length $0.88-0,90 \mathrm{~mm}$; distal pale spot in $r_{3}$ rounded, not reaching wing margin; anal cell with one, large, distal pale spot

C. sherlocki Felippe-Bauer \& Trindade

- Large species, wing length $1.47 \mathrm{~mm}$; distal pale spot in $r_{3}$ oblique, broadly reaching wing margin; anal cell with two distal small, round, pale spot.. C. wallace $i$ Wirth \& Blanton

11. PR 2.8-3.0. 12

- PR 1.8-2.5 14

12. Distal pale spot in $r_{3}$ double; basal pale spot in $m_{1}$ small, not connected with the basal pale spot in $\mathrm{m}_{2}$; distal pale spot in $\mathrm{m}_{2}$ not reaching wing margin.

C. avilaensis Ortiz \& Mirsa

- Distal pale spot in $\mathrm{r}_{3}$ single; basal pale spot in $\mathrm{m}_{1}$ large, slightly connected with the basal pale spot in $\mathrm{m}_{2}$; distal pale spot in $\mathrm{m}_{2}$ reaching wing margin................. 13

13. Large species, wing length $1.80 \mathrm{~mm}$; one distal pale spot in anal cell; pale spot on $\mathrm{M}_{1}$ restricted to extreme apex, connected with the distal pale spot in $\mathrm{r}_{3}$ and $\mathrm{m}_{1}$...................................... C. discrepans Ortiz \& Mirsa

- Smaller species, wing length $1.20 \mathrm{~mm}$; two distal pale spot in anal cell; pale spot on apical $1 / 2$ of $\mathrm{M}_{1}$ C. lenti Tavares \& Luna Dias

14. AR 1.31-1.33; third palpal segment with a shallow, broad pit; parameres straight in mid portion, abruptly curved ventrally to simple tip, without lateral fringe of spines; apex of aedeagus slender and rounded............................... C. mojingaensis Wirth \& Blanton

- AR 0.77-1.21; third palpal segment with a moderately deep pit; parameres and aedeagus various ......... 15

15. Flagellomeres 8, 9 subequal, AR 0.77-0.89; sensilla coeloconica on flagellomeres 1, 6-8.

C. aldomari Felippe-Bauer \& Trindade.

- Flagellomere 8 clearly shorter than 9 , AR 0.98-1.21; sensilla coeloconica on flagellomeres 1, (4), 5-8........ 16

16. Poststigmatic pale spot without dark spot behind second radial cell; anal cell with two distal connected pale spots.................................... C. barthi Tavares \& Souza

- Poststigmatic pale spot with dark spot just behind second radial cell; anal cell with two distal separated pale spots.

17. AR 1.15-1.21; base of the wing with a pale band extending from costal vein to wing margin in anal cell; distal pale spots in anal cell oblique, the proximal one in the midlength of $\mathrm{CuA}$; poststigmatic pale not divided by the dark spot behind second radial cell; distal portion of the parameres slender, without ventral expansion or lobe, tapered to simple tip without lateral fringe of spines; aedeagus ending in a simple tip....

C. azureus Wirth \& Blanton 
- AR 0.98-1.08; base of the wing with a pale band extending from costal vein to proximal portion of anal cell; distal pale spots in anal cell longitudinally aligned, the proximal one near mediocubital fork; poststigmatic pale divided by the dark spot behind second radial cell; distal portion of the parameres with well developed ventral expansion or lobe, tapered to simple tip with lateral fringe of fine spines; aedeagus ending in a bifid tip. 18

18. Apex of aedeagus, long, slender, with bifid point laterally directed.............. C. dicrourus Wirth \& Blanton

- Apex of aedeagus like a clamp process directly connected to the basal arch......... C. macieli Tavares \& Ruiz

\section{C. aldomari Felippe-Bauer \& Trindade, sp. nov.} (Figs 1-7)

Diagnosis - Only species in the subgenus Mataemyia Vargas with the following combination of characters: medium-sized, eyes narrowly separated, flagellomeres 8 and 9 subequal, sensilla coeloconica on flagellomeres 1, 6-8, AR 0.77-0.89, PR 2.0-2.2.

Female - Head - Brown. Eyes (Fig. 2) separated by distance equal to diameter of $1 / 2$ ommatidia. Flagellum (Fig. 1) pale brown, flagellomeres vasiform, without transition in length between proximal and distal series; antennal ratio $0.77-0.89(0.82, \mathrm{n}=10)$; sensilla coeloconica on flagellomeres $1,6-8$, one on 1 , two on 6-7, three or four on 8. Palpus (Fig. 4) brown; third segment stout with deep sensory pit on mid length; palpal ratio 2.0-2.2 $(2.1 \mathrm{n}=9)$. Proboscis short; $\mathrm{P} / \mathrm{H}$ ratio $0.67-0.75(0.71, \mathrm{n}=$ 10); mandible with 12-14 $(\mathrm{n}=6)$ teeth.

Thorax - Dark brown. Scutum with prominent pattern of oval yellowish patches; scutellum yellowish on sides; postscutellum brown. Wing (Fig. 3) with contrasting pattern: second radial cell in dark spot; pale spot over R-M large, extending from $\mathrm{M}_{1}$ to costal margin (in some specimens extending from $\mathrm{CuA}_{1}$ to costal margin), poststigmatic pale spot in $\mathrm{r}_{3}$ extending behind second radial cell, nearly isolating small dark spot that sometimes is connected to the oblique dark line in $r_{3}$, separating the poststigmatic pale spots; distal pale spot in $r_{3}$ broadly reaching wing margin or nearly rounded and not reaching wing margin; $\mathrm{m}_{1}$ with two pale spots, distal one usually meeting wing margin; $\mathrm{m}_{2}$ with four pale spots, one in front of mediocubital fork, second behind medial fork, third in the middle of cell, forth reaching wing margin; cua ${ }_{1}$ with rounded pale spot nearly reaching wing margin; anal cell with two distal rounded pale spots; wing base with broad pale spot extending from costal margin to anal cell; $\mathrm{M}_{1}$ and $\mathrm{M}_{2}$ faint pale, $\mathrm{CuA}_{1}$ and $\mathrm{CuA}$ dark; macrotrichia scarce in distal half of wing; wing length $0.80-0.88(0.83, \mathrm{n}=10) \mathrm{mm}$; breadth $0.40-0.43(0.42, \mathrm{n}=$ 10) $\mathrm{mm}$; costal ratio $0.60-0.62(0.61, \mathrm{n}=10)$. Halter pale. Legs (Fig. 7) mostly brown; femora with subapical pale bands (in some specimens faint in hind femur), tibiae with subbasal pale bands; hind tibia with a large and faint pale band apically; hind tibial comb (Fig. 6) with four spines, the two nearest the spur longest, subequal.

Abdomen - Dark brown. Two slightly unequal or sometimes subequal, ovoid spermathecae with long necks $(10 \mu \mathrm{m})$, measuring 49 by $31 \mu \mathrm{m}, 45$ by $29 \mu \mathrm{m}$
(Fig. 5); long, slender third spermatheca $(30 \mu \mathrm{m})$, sclerotized ring present.

\section{Male - Unknown.}

Type data and depository - Holotype female, Fazenda Gavião, Forest, Ourém, PA, 129'44'S 47 13'7'W 28-29. XI.2008, CDC light trap, Trindade \& Guimarães col. (MPEG). Paratypes nine females as follows: two, same data as holotype, except curral, $1^{\circ} 29^{\prime} 39^{\prime \prime} \mathrm{S} 47^{\circ} 13^{\prime} 16^{\prime \prime} \mathrm{W}$ (MPEG; \#468 CCER); three, same data as holotype, except 26-27.XI.2008 (MPEG; \#469 CCER); two, same data as holotype, except 27-28.XI.2008 (MPEG: \#470 CCER); one, same data as holotype, except 29-30.XI.2008 (MPEG) and one paratype, Fazenda Rezende, Comunidade do Café Torrado, Juruti, $02^{\circ} 18^{\prime} 77.3^{\prime \prime S} 56^{\circ} 05^{\prime 2} 244.4^{\prime \prime} \mathrm{W}, 17-18$. XII.2007, CDC light trap, Trindade col. (MPEG).

\section{Distribution - PA.}

Etymology - This species is named in honour to Aldomar Aairão Monteiro, resident in the field area in recognition of his continuous support.

Taxonomic discussion - C. aldomari has similar wing pattern to that of $C$. azureus Wirth \& Blanton, C. barthi Tavares \& Souza, C. felippebauerae Spinelli and C. mojingaensis Wirth \& Blanton, but it can be distinguished from these species by the smaller wing 0.80 0.88 (1.02-1.09 in C. azureus, 1.20 in C. barthi, 0.96-1.20 in C. felippebauerae, 0.89-1.02 in C. mojingaensis), darker lumen of the second radial cell (pale lumen in the others species), by the small dark spot in $r_{3}$ located on the distal end of second radial cell (without defined dark spot in C. barthi, dark spot behind second radial cell in C. azureus, C. felippebauerae and C. mojingaensis) and by the flagellomeres without transition in length between proximal and distal series (flagellomeres 9-12 more elongated than 2-8 in the others species).

\section{C. sherlocki Felippe-Bauer \& Trindade, sp. nov.} (Figs 8-14)

Diagnosis - Only species in the subgenus Mataemyia Vargas with the following combination of characters: medium size, eyes contiguous, sensilla coeloconica on flagellomeres 1, 6-8, AR 0.84, distal pale spot in $r_{3}$ rounded not reaching wing margin and anal cell with one, large, distal pale spot, hind femur dark to tip.

Female - Head - Brown. Eyes (Fig. 9) nearly contiguous. Flagellum pale brown, with transition in length between proximal and distal series; antennal ratio $0.84(\mathrm{n}=$ 1); sensilla coeloconica (Fig. 8) on flagellomeres 1, 6-8. Palpus (Fig. 11) brown; third segment stout with moderately deep sensory pit on mid length; palpal ratio 2.3 (n $=1)$. Proboscis short; $\mathrm{P} / \mathrm{H}$ ratio $0.64-0.66(0.65, \mathrm{n}=2)$; mandible with nine $(\mathrm{n}=1)$ teeth.

Thorax - Dark brown. Scutum without definite pattern in slide mounted specimens; scutellum, postscutellum brown. Wing with contrasting pattern as in Fig. 10: second radial cell in dark spot; pale spot over R-M large, extending from $\mathrm{M}_{1}$ to costal margin, poststigmatic pale spot in $\mathrm{r}_{3}$ extending behind second radial cell, nearly isolating small dark spot that in one specimen is connected to the 
oblique dark line in $\mathrm{r}_{3}$, separating the poststigmatic pale spots; distal pale spot in $\mathrm{r}_{3}$ rounded, located in the middle of cell, not reaching wing margin and $\mathrm{M}_{1} ; \mathrm{m}_{1}$ with two pale spots, distal most far from wing margin; $\mathrm{m}_{2}$ with three pale spots, one between medial, mediocubital forks, connected with subapical pale spot, distal one reaching wing margin; cua $_{1}$ with rounded, large pale spot reaching wing margin; anal cell with large distal spot, broadly reaching wing margin, connected with pale spot on wing base, which extends from costal margin to anal cell; $\mathrm{M}_{1}$ and $\mathrm{M}_{2}$ dark in distal $1 / 2, \mathrm{CuA}_{1}$ and $\mathrm{CuA}_{2}$ dark; macrotrichia present on distal margin of wing; wing length $0.88-0.90(0.89, \mathrm{n}=2)$ $\mathrm{mm}$; breadth 0.43-0.45 $(0.44, \mathrm{n}=2)$; costal ratio $0.64(\mathrm{n}=$ 2). Halter knob brown. Legs (Fig. 14) mostly brown; fore-, mid femur with subapical pale bands, tibiae with subbasal pale bands; hind tibial comb (Fig. 13) with four spines, the two nearest the spur longest, subequal.

Abdomen - Dark brown. Two subequal, ovoid spermathecae, measuring 31 by $26 \mu \mathrm{m}, 30$ by $26 \mu \mathrm{m}$ (Fig. $12)$; long, slender third spermatheca $(13 \mu \mathrm{m})$, sclerotized ring present.

\section{Male - Unknown}

Type data and depository - Holotype female, Fazenda Rezende Comunidade do Café Torrado, Juruti, PA, "barn", CDC light trap, 06-07.IV.2008, DDR Guimarães, E Mon-

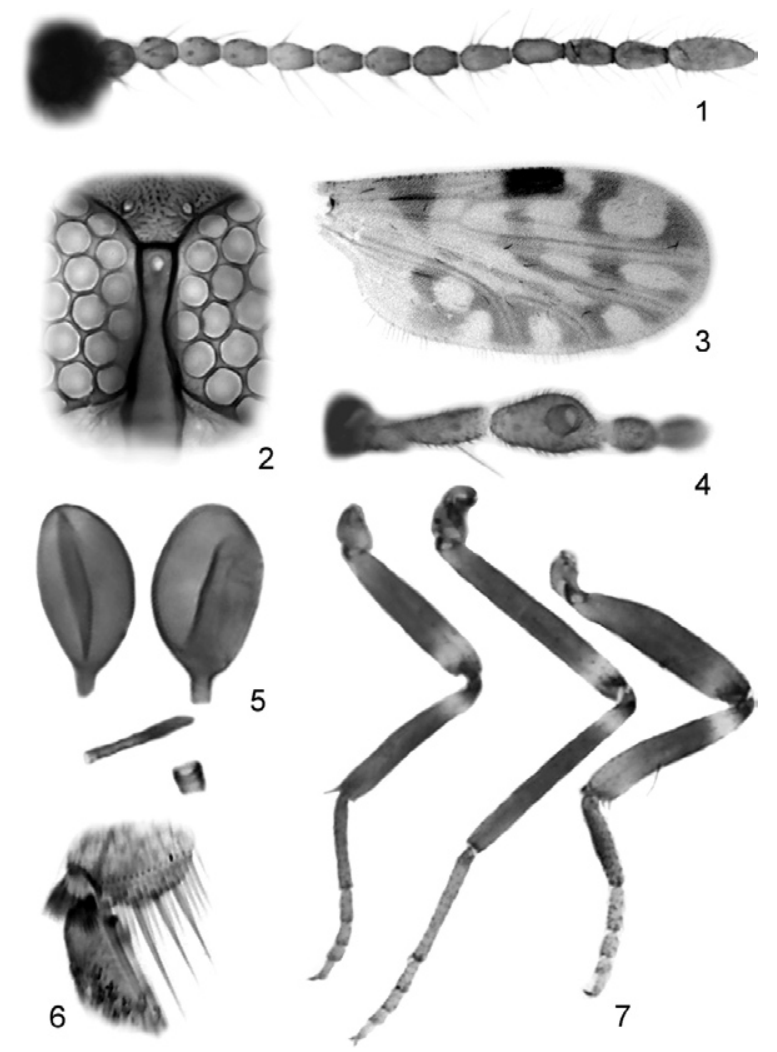

Figs 1-7: Culicoides aldomari sp. nov., female; 1: flagellomeres 1-13; 2: eyes separation; 3: wing photograph; 4: palpus; 5: spermathecae, third spermatheca and sclerotized ring present; 6 : hind tibial comb; 7: legs (left to right) fore, mid and hind. teiro \& A Quaresma cols. (MPEG). Paratype female, same data as holotype, except 07.IV.2008, 06:00 pm-09:00 pm, RL Trindade \& DDR Guimarães cols. (\#471 CCER).

\section{Distribution - PA.}

Etymology - This species is named in honour to $\mathrm{Dr}$ Italo Sherlock in recognition of his important contributions in the knowledge of the tropical maladies, especially leishmaniasis.

Taxonomic discussion - C. sherlocki shows the hind femur dark to tip as in C. bricenoi Ortiz, C. cuiabai Wirth and C. wallacei Wirth \& Blanton. However, it can be distinguished from the two first mentioned species by the wing pattern, by the subequal first and second radial cells (2nd radial cell 2x longer than 1st in C. bricenoi and C. cuiabai) and by the AR 0.84 (1.70 in C. bricenoi and 1.47 in C. cuiabai). From C. wallacei Wirth \& Blanton can be distinguished by the smaller length, by the rounded distal pale spot in $r_{3}$ not reaching wing margin and by the presence of one, large distal pale spot in anal cell.

\section{ACKNOWLEDGEMENTS}

To Aldomar Aairão Monteiro, for kindly permission of fieldwork in his property, to Therezinha Pimentel, for providing financial support for the fieldwork, to Domingos Guimarães, Emerson Monteiro and Luis Augusto Quaresma, for assistance
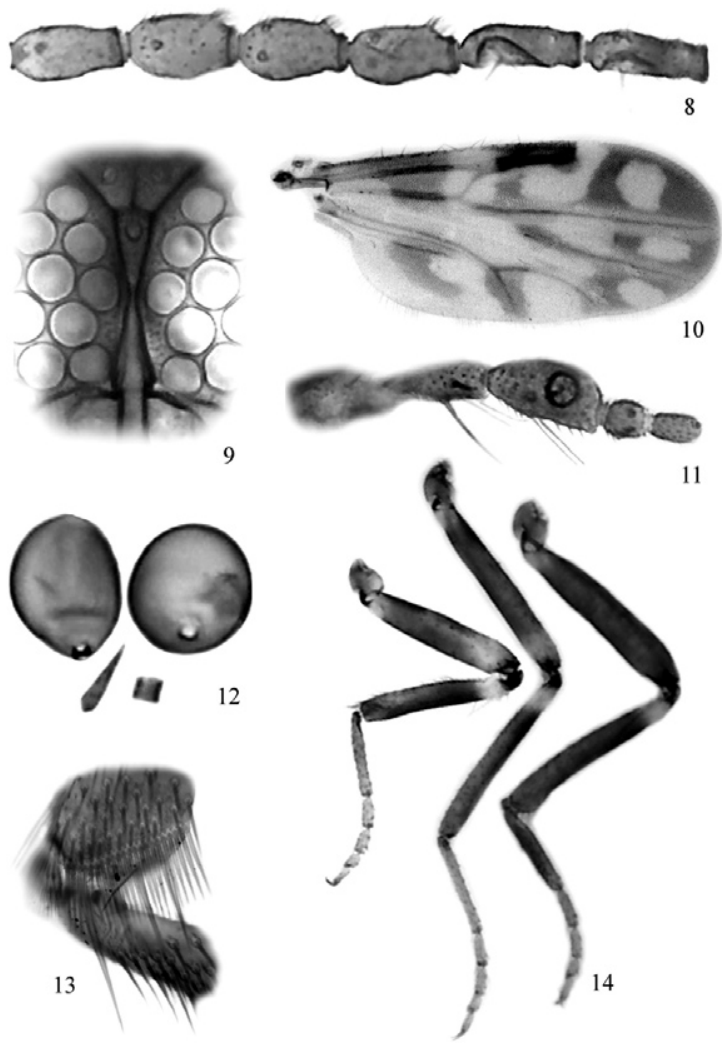

Figs 8-14: Culicoides sherlocki sp. nov., female; 8: flagellomeres 5-10; 9: eyes separation; 10: wing photograph; 11: palpus; 12: spermathecae, third spermatheca and sclerotized ring present; 13: hind tibial comb; 14: legs (left to right) fore, mid and hind. 
in the fieldwork, to Rodrigo Mexas, for assistance with wing photographs, and to Orlando Tobias Silveira and Inocêncio S. Gorayeb, for providing logistic support for this study.

\section{REFERENCES}

Borkent A 2012. The subgeneric classification of species of Culicoides - thoughts and a warning. [Accessed in February 2012]. Available from: inhs.uiuc.edu/research/FLYTREE/CulicoidesSubgenera.pdf.

Borkent A, Spinelli GR 2000. Catalog of the New World biting midges south of the United States of America (Diptera: Ceratopogonidae). Contrib Entomol Int 4: 1-107.

Brown BV, Borkent A, Cumming JM, Wood DM, Woodley NE, Zumbado MA 2009. Manual of Central American Diptera, Vol. 1, NRC Research Press, Ottawa, 714 pp.

Felippe-Bauer ML 2003. A importância do padrão das manchas das asas em Culicoides (Latreille, 1809) (Diptera: Ceratopogonidae). Entomol Vect 10: 595-600.
Spinelli GR, Ronderos MM, Marino PI, Carrasco DS, Ferreira RLM 2007. Description of Culicoides (Mataemyia) felippebauerae sp. n., Forcipomyia musae immatures and occurrence of $F$. genualis, breeding in banana stems in Brazilian Amazonia (Diptera: Ceratopogonidae). Mem Inst Oswaldo Cruz 102: 659-669.

Trindade RL, Gorayeb IS 2005. Maruins (Ceratopogonidae: Diptera) do estuário do Rio Pará e do litoral do estado do Pará, Brasil. Entomol Vect 12: 61-74.

Wirth WW, Blanton FS 1973. A review of the maruins or biting midges of the genus Culicoides (Diptera: Ceratopogonidae) in the Amazon Basin. Amazoniana 4: 405-470.

Wirth WW, Marston N 1968. A method for mounting small insects on microscope slides in Canada Balsam. Ann Entomol Soc Am 61: 783-784.

Wirth WW, Soria SJ 1981. Two Culicoides biting midges reared from inflorescences of Calathea in Brazil and Colombia and a key to the species of the discrepans group (Diptera: Ceratopogonidae). Rev Theobroma 11: 107-117. 